Biologín Tropical

\title{
Does Echinoderm research deserve an ethical consideration?
}

\author{
Tamara Rubilar ${ }^{1} \&$ Augusto Crespi-Abril ${ }^{1,2}$ \\ 1. Laboratorio de Oceanografía Biológica (LOBio), Centro para el Estudio de Sistemas Marinos (CESIMAR- \\ CONICET), Boulevard Brown 2915, Puerto Madryn 9120, Argentina; rubilar@cenpat-conicet.gob.ar; \\ crespi@cenpat-conicet.gob.ar \\ 2. Universidad Nacional de la Patagonia San Juan Bosco, Boulevard Brown 2930, Puerto Madryn 9120, Argentina
}

\author{
Received 09-XII-2016. Corrected 04-III-2017. Accepted 20-VI-2017.
}

\begin{abstract}
Traditional ethics reflection centers the discussion in conflicts that affect humans. According to epistemology-based ethics, facts are needed to include other living beings as object of ethical consideration. In this sense, huge efforts have been made to demonstrate that animal suffering is real. However, the ethical reflection only reaches large vertebrates and some species of small ones, excluding invertebrates. However, a different approach (ethic-based epistemology) is equally valid and questions the assumptions of traditional ethics. This new insight does not demand facts to demonstrate that living beings should be considered ethically, since ethics should be first than epistemology (facts). Thus, all living beings should be treated with respect and a relationship based on empathy should be established. In this context, we discuss all the advances made in echinoderm research in the last 3000 years and the different uses humans made of these organisms. Finally we emphasize that, when studying echinoderms, a reflection about our behavior as researchers is necessary, and we encourage the use of ethically responsible research. Rev. Biol. Trop. 65(Suppl. 1): S11-S22. Epub 2017 November 01.
\end{abstract}

Key words: Ethics; Echinodermata; antropocentric doctrine; non-antropocentric doctrine; 3Rs principle.

\section{ETHICS AND NATURE}

In general terms, ethics thinks on situations that involves some types of conflicts. There are several kinds of conflicts in science, but not all of them deserve ethical reflection. The most accepted criterion to establish the pertinence of an ethical reflection is if it affects humans in some way (Guariglia \& Videla, 2011). This point of view considers clearly that all humans' beings are considered as subject of moral concern (anthropocentric doctrine). However, this is not the same for other living beings (non-anthropocentric). In this sense, it is difficult to determine which living beings should be taken as object of ethical consideration. One approach is to establish if the living beings satisfy criteria for sentience or consciousness (capacity to have positive and negative experiencies) which involve behavioral, evolutionary and physiological considerations, using humans as a benchmark (Edelman \& Seth, 2009). The arguments to determine which living being should be included into the field of ethical reflection are then supported by scientific facts (Chandroo, Yue, \& Moccia, 2004; Griffin \& Speck, 2004; Ellwood, 2011; Lewbart \& Mosley, 2012; Mather, 2015). This approach has been described as epistemologybased ethics (Cheney \& Weston, 1999; Weston, 2009) and it assumes several points such as that only human are the subject of ethics, and that ethical theories can be adjusted to retrofit all new ethical conflicts. However, Weston (2009) has proposed the ethics-based epistemology approach. This approach focuses on the most obvious assumption of all: that the world consists of a collection of more or less given facts to which we must respond. Ethics then systematizes and unites these responses. 
What would happen if actually, the necessary relation is inverted? What if the world we live in arises mainly from our ethical practice, rather than the epistemological practice? The main assumption of the ethics-based epistemology is that ethical action should come first (Cheney \& Weston, 1999; Weston, 2009). Usually, to decide which organism is deserving of ethical practice first it is necessary to know if they are conscious (Edelman \& Seth, 2009). However, we will have no idea which animals are actually conscious until we have already approached them ethically. Therefore, we propose that it is first needed to establish a respectful relationship with them rather than a facts-based relationship.

\section{ECHINODERM THROUGH 3000 YEARS OF HISTORY}

Echinodermata is a Phylum of deuterostomes that are exclusively marine invertebrates. They are diverse and widely distributed in all marine environments and play crucial roles in each environment (Brusca, Moore, Schuster, 2016). The Phylum comprises approximately 7000 species (Smith, 2005) and from the Ordovician (around 495-440 million years ago) their basic characteristics have not changed (Telford et al., 2014).

Human knowledge regarding this Phylum goes far back to prehistoric times, since humans have consumed sea urchins throughout their history (Lawrence, 2007). They are represented in artwork dating back 4000 years in the "frescos cretenses". Sea cucumbers have also long been consumed and used for medicinal purposes in the eastern cultures (Brown \& Eddy, 2015). The most ancient description of an echinoderm was performed by Aristotle (350 B.C.E.), more than 2000 years ago, who described in Historia Animalium the feeding apparatus of the sea urchins, today known as Aristoteles' Lantern (Fig. 1A). However, Aristotle knew the echinoderms as ostracoderms. However, 2000 years had to pass until the nature interested the scholars of the times and animals were studied again. In particular, the name Echinodermata was coined by Klein in 1734 in its Naturalis dispositio echinodermatum (Figure 1B, C). Nevertheless, he only used it to refer to sea urchins and not all the classes known today. Linnæus placed the genera Asterias, Echinus and Holothuria under the group Mollusca in the 10th Edition of Systema Naturae (1758). The term Echinodermata was used again in 1792 by Brugiere who recognized

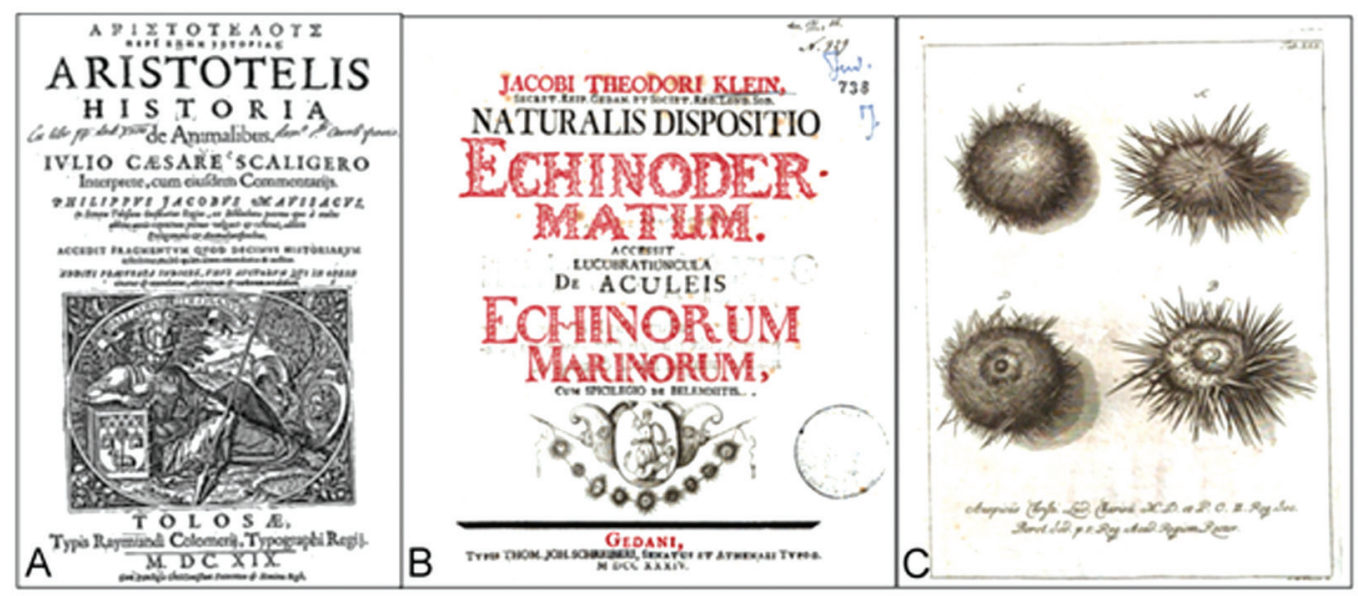

Fig. 1. First descriptions of echinoderms through history. A) Cover of Historia Animalum by Aristotle, B) Cover of Naturalis dispositio echinodermatum by Klein, C) Drawing of sea urchin from Klein.

Fig. 1. Primeras descripciones de equinodermos a lo largo de la historia. A) Portada de Historia Animalum escrito por Aristóteles, B) Portada de Naturalis dispositio echinodermatum escrito por Klein, C) Dibujo de erizo de mar hecho por Klein. 
these animals as a distinct group of invertebrates, but sea cucumbers were not included. However, later on Lamarck (1809) placed the Echinodermata together with the actual group Coelenterata in the Radiata groups of invertebrate. Over forty years had to pass until De Tornos (1839) and Salacroux (1840) used the term Echinodermata. Later on, in 1854 Leuckart, argued that Echinodermata did not belong with Coelelenterata due to its higher grade of structure. Since that time Echinodermata has been a single clade among the invertebrates.

Species description of Echinodermata dominated the literature since the XIX century, first with species inhabiting the coasts of Europe (i.e. Frey \& Leuckart, 1847), followed by species from all around the world due to the oceanographic expeditions. Since the XIX century oceanographic expeditions have not stopped. It would be extremely extensive to name every one of the expeditions and the papers produced from them, although the first's ones are worth naming since they were pioneer. The HMS Challenger and the Albatross were followed by hundreds all around the world, recently also exploring the deep sea species, in addition to all the intertidal and shallow water species (i.e. Agassiz, 1881; Théel, 1882; Agassiz, 1890; Clark, 1902; De Morgan, 1913). Considering that for over 300 years echinoderms have been collected all around the world to describe species, determine their distributions and generate collections in museums it is possible to assume that several hundred thousands of echinoderms were collected and fixed without any ethical reflection.

Echinoderms are also used as experimental models, since the popularization of the microscope among scientists. From the middle of the XIX century, sea urchins embryos started to be used as animal models, because the gametes were easy to obtain and their optical transparency made this organism a great model. Dufossé and Derbès (1847) outlined the phenomena of fertilization and the development of the sea urchin embryo through metamorphosis. Even though the studies of these two authors appeared to be lost in the scientific literature
(Briggs \& Wessel, 2006), sea urchins embryos were still used as models organism. Hertwig (1876) discovered that the sperm entered the female gamete and that the binding of the two produced an embryo in the sea urchin Toxopneustes lividus. Since then, sea urchin embryos were accepted as the best model for embryonic research and have been used to elucidate developmental issues such as mechanisms of fertilization, egg activation, cleavage, gastrulation and regulation of differentiation in the early embryo, as well as models in numerous types of studies ever since such us nervous system development, development evolution, regeneration, etc (i.e. Boveri, 1901; Dolmatov, 1988; Briggs \& Wessel 2006; McClay, 2011; Garner et al., 2016; http://www.echinobase. org) (Figure 2B,C, D). During the beginning of the XX century, sea stars were added as model organisms. Metchnikoff (1893) first observed a cellular immune response in the bipinnaria larvae sea stars. After injury the ectoderm of the larvae, mesenchymal cells quickly migrated to the site of the injury. Moreover, he discovered that amoeboid cells had phagocytic activities of (Metchnikoff, 1893). Despite this great discovery, the use of echinoderm larvae as model organism in immunology did not start until the XXI century (Figure 2A) (Pinsino, Thorndyke \& Matranga, 2007; Furukawa, Funabashi, Matsumoto \& Kaneko, 2012; Ho, 2015). The ability to eviscerate and posterior regeneration of sea cucumber has made them excellent models in regeneration studies, as well as brittle stars and seastar since they can regenerate their arms (i.e. Candia-Carnevali, Bonasoro, Lucca, Thorndyke, 1995; Dolmatov \& Ginanova, 2001; Candelaria, Murray, File, García-Arrarás, 2006; San Miguel-Ruiz \& García-Arrarás, 2007; Mashanov, Zueva, Heinzeiller, 2008). The technological advances and new tools available made echinoderms excellent model organisms for both scientific and teaching purposes (i.e. Eisen, 1995; Burke et al., 2006; www.Echinobase.org). In most studies, individuals are often manipulated alive, sometimes lightly anesthetized with $\mathrm{Cl}_{2} \mathrm{Mg}$ in different concentrations. 

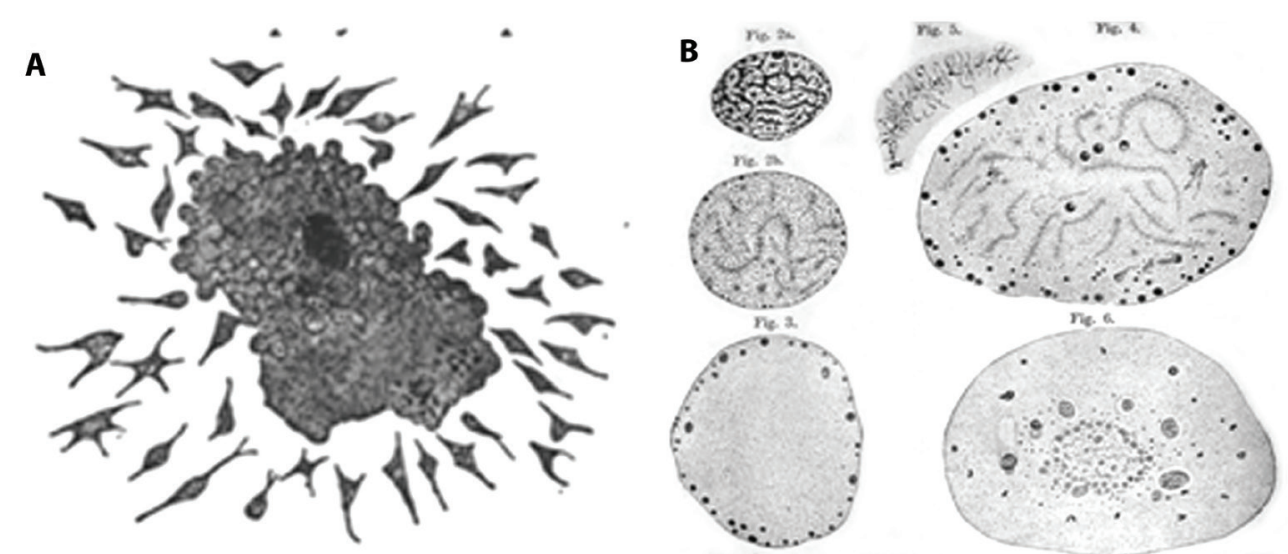

Fig. 32.-Collection of phagecytes round a

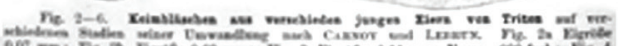

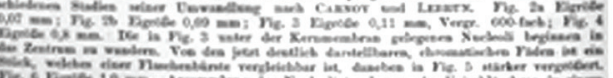
splioter. Bipinvaria asterigera.
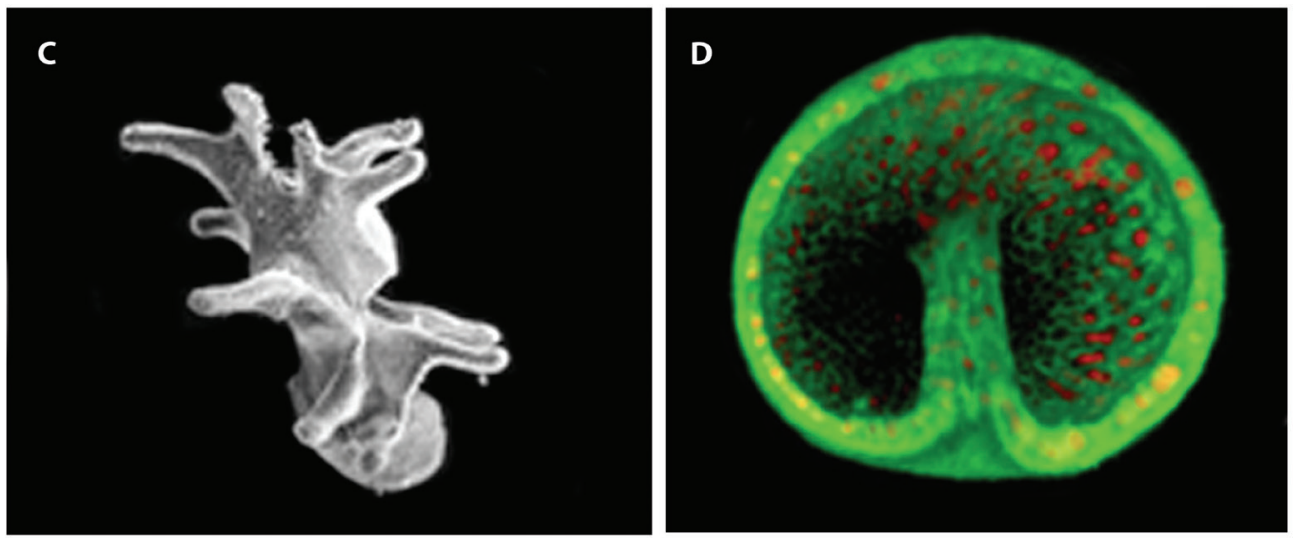

Fig. 2. Use of echinoderm embryos as research model. A) Original figure from Ilya Merchinkoff study showing an phagocyte, B) Original figure from Hertwig showing the changes in the egg of a sea urchin after fertilization, C) Bipinnaria larva of Patiria miniata view in SEM (photo by Andrew Cameron from EchinoBase), D) Gastrula of Strongylocentrotus purpuratus (photo by Emanuel Fuare from EchinoBase).

Fig. 2. Uso de los embriones de equinodermos como modelos en la investigación. A) Figura original del studio de Illya Merchinkoff mostrando un fagocito, B) Figura original de Hertwig mostrando los cambios en el huevo de un erizo de mar luego de la fecundacion, C) Larva bipinnaria de Patiria miniata observada en MEB (foto tomada por Andrew Cameron de Echinobase), D) Gastrula de Strongylocentrotus purpuratus (foto tomada por Emanuel Fuare de Echinobase).

Echinoderms are highly demanded in research and teaching without a real concern at the suffering and to the respect living beings deserve. This calls for a serious ethical reflection.

\section{ETHICS BASED IN FACTS}

In epistemology-based ethics, reflections are supported by scientific facts. Therefore, organisms first should have to satisfy criteria for sentience or consciousness using humans as benchmark (Edelman \& Seth, 2009). Behavioral, evolutionary and physiological considerations must be taken in account according to this approach. Echinoderms are highly complex organisms. They are invertebrates that along with hemichordates, form a sister clade to Chordata, and together comprise the Deuterostomia (Figure 3) (Swalla \& Smith, 2008). 


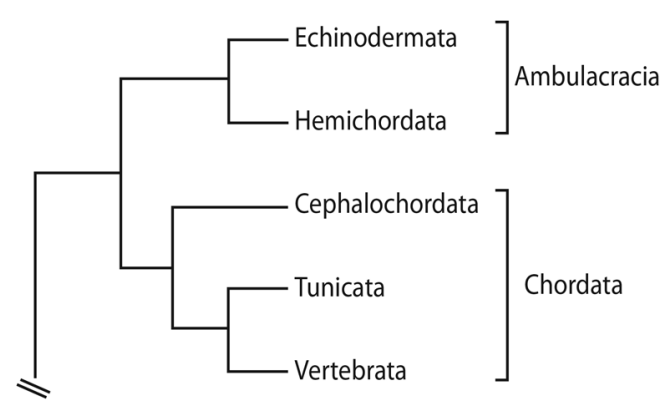

Fig. 3. Current deuterostome phylogeny, according to evolutionary developmental biology, molecular phylogeny and nuclear and mitochondrial genomics (From Swalla and Smith, 2008).

Fig. 3. Filogenia actual de deuterostomados de acuerdo a filogenia del desarrollo, biológica y molecular y a genómica nuclear y mitocondrial (Figura de Swalla y Smith, 2008).

This relation is supported by evolutionary developmental biology, molecular phylogeny and nuclear and mitochondrial genomics (Halanych, 1995; Cameron, Garey, \& Swalla, 2000; Perseke, Golombek, Schlegel, \& Struck, 2013). Even though the nervous system in this clade was always described as enigmatic and diffuse it is now know that echinoderms have a centralized nervous system, probably a plesiomorphic (ancestral) condition of the deuterostomia, highly developed and complex with presence of the major neurotransmitters that are found in mammalian brains (Mashanov, Zueva, Rubilar, Epherra, \& García-Arrarás, 2016). It is also known that sensorial organs are widely distributed through their body, for example they have statocysts that forms organs of equilibrium (Lewis, 1968; Ehlers, 1997); in sea urchins there is a spatial vision with reasonable acuity necessary for shelter and seeking and predatory avoidance (Yerramilli and Johnsen, 2009) and it has been suggested that there is a complex integrative functions since the entire sea urchin skeleton would function as a huge compound eye (Ullrich-Lütera, Dupont, Arboleda, Hausend, \& Narnonec, 2011). Chemoreception is found in many classes of echinoderms and trigger escape responses, aggregation and spawning events (Moore \& Lepp, 1997; Campbell, Coppard, D`Abreo, \& Thomas, 2001; Hagen,
Andersen, \& Stabell, 2002; Brewer \& Konar, 2005; Raible et al., 2006; Mercier \& Hammel, 2009). And even though there are yet no studies which have determine pain in echinoderm, there is evidence of nociception, the response to noxious stimuli (Campbell, Coppard, D’Abreo, $\&$ Thomas, 2001) and further research regarding this issue is necessary. However, the facts are that when echinoderms are taken outside of the seawater for measuring, weighting, extraction of gametes, dissection or fixation, animals start to lose seawater and respiration becomes difficult. The lack of oxygen and loss of liquid produces a loss of homeostasis in the organism, most probably followed by suffering and an agonizing death.

\section{ETHICS BASED ON RESPECT}

Even if we did not have these facts regarding echinoderms, we do have ethical values that can be applied to other living beings. These values are mainly focus on the respect for the value of life and the welfare of the organisms and they establish limits to our actions forcing us to establish a relationship based on respect to others living beings (Guariglia \& Videla, 2011). In the first place it is necessary to rethink if knowledge regarding the biology, physiology, ecology of animals are over the welfare of living beings and should generate an ethical response. To do as you would be done should be an important principle to leading treat living beings with respect (to feel empathy for living beings). This means to include not polluting their environment but avoiding (or minimizing) exposure to experimental conditions that might cause pain or suffering. This means implementing a holistic environmental ethics (Leopold, 1949). The inability of echinoderms to explicitly communicate their state of being makes it extremely difficult to measure the suffering. However, there are clues that should be taken into account during manipulation and experimentation. These are loss of water, loss of movement outside the water, inability to turn over in the seawater, lack of movement inside the water, podia retraction, loss of spines, loss 
TABLE 1

Guidelines to handling echinoderm

CUADRO 1

Guía para trabajar con equinodermos

\begin{tabular}{ll}
\multicolumn{1}{c}{ Stage } \\
Collection
\end{tabular}

of turgence in the epidermis, inflammation of the dermis, decoloration (Jangoux, 1984; Hernández, Buckle, Guisado, Barón, \& Estavillo, 2004). Welfare measures would include careful capture, transportation, housing, feeding, health and finally in many cases killing the animals at the end of the experiment (Table 1). In echinoderms welfare also includes ensuring that the aquaria are clean, adequate salinity and temperature, seawater in good conditions, proper feeding is considered, etc (Table 2).

\section{WHAT CAN BE DONE?}

Science should not be halted since scientific progress is necessary for human welfare. However, we need to rethink how science is done and include empathy for living beings, which means that all living beings should be taken as object of ethical consideration. Throughout history aesthetics has been used as a fundamental stone to establish ethical boundaries. Although many species were endangered, only charismatic species were first considered to be protected due to their vulnerability (i.e. Panda, Whales, Chimpanzee). After the increase in the number (and complexity) of cases of animal experiments and manipulation, society started to pressure scientists to consider ethically more species (mainly small vertebrates), therefore, ethics were later used to regulate vertebrates as a whole in standard scientific procedures (i.e. Dess \& Foltin, 2005). Canada was a pioneer in applying regulations to use experiment animals through the Canadian Council of Animal Care (Council, 1984), however it was restricted to non-human primates and mice. Only 10 years ago one group of invertebrates (cephalopods) were included in the ethical discussion. 
This discussion derived in the development and application of specific protocols to be used when studying cephalopods (Vidal et al., 2014). The basic principles to be taken into account for the welfare of animals used in research are the 3 Rs (Replacement, Reduction and Refinement) (Russel \& Burch, 1959). First, the substitution of the species should be considered (Replacement). For instance, the development of non animal research techniques (cell and tissue studies, new scanning methods, etc) and have lead to reduce the situations where animals are needed. However, if using animals is still necessary and for example and experiment that requires sampling of numerous specimens is to be done, the species with the highest population density has to be chosen and endangered species should be avoided. Then, if the species cannot be replaced then the number of individuals is to be considered (Reduction). For example, are 50 individuals really necessary or can the study be done with 20 ? Finally, we should minimize suffering and deaths and improve animal welfare (Refinement) (see www.nc3rs.org.uk for details).

The development of appropriate specific standard protocols for performing experiments, manipulation and sacrifice are necessary. In the meantime these guidelines are to be followed to ensure the welfare of echinoderms (Table 2 and 3):

Guidelines to handle echinoderms: Echinoderms must be handled very carefully during

TABLE 2

Physical parameters needed to maintain echinoderm in captivity

CUADRO 2

Parámetros físicos necesarios para mantener equinodermos en cautividad

\begin{tabular}{|c|c|c|c|}
\hline Parameter & Range Value & Observations & References \\
\hline Oxygen & $\cdot>80 \%$ & $\begin{array}{l}\text { To make sure that } \mathrm{O}_{2} \text { is in appropiate values, } \\
\text { air should be provided in the aquarium }\end{array}$ & - Grosjean et al., 1998 \\
\hline Temperature & - close to environment & $\begin{array}{l}\text { Depends of the time of the year the animals } \\
\text { were collected }\end{array}$ & $\begin{array}{l}\text { - Hernández et al., } 2004 \\
\text { • Sherman, } 2015\end{array}$ \\
\hline Salinity & • $30-35 \% 0$ & $\begin{array}{l}\text { Salinity below } 28 \% \text { and above } 36 \% \text { should be } \\
\text { completely avoided, over } 40 \% \text { and below } 25 \\
\% \text { mortality will be assure }\end{array}$ & •Lawrence, 1975 \\
\hline Water circulation & •1-1.5 L.min-1 & $\begin{array}{l}\text { Water circulation is neccesary for proper respiration } \\
\text { and feeding. Avoid higher values to prevent } \\
\text { detachement of individuals from the surface }\end{array}$ & $\begin{array}{l}\cdot \text { Repohlo, } 2012 \\
\text { • Grosjean et al., } 1998\end{array}$ \\
\hline Photoperiod & - close to environment & $\begin{array}{l}\text { Photoperiod has an important effect on gametogenesis, } \\
\text { when possible establish it as in the field, if not possible } \\
\text { 12:12 conditions are suitable }\end{array}$ & • Mercier \& Hamel, 2009 \\
\hline $\mathrm{pH}$ & $\bullet-7.8-8.2$ & $\begin{array}{l}\text { It should be closely controlled, at least on } \\
\text { a weekly-basis }\end{array}$ & $\begin{array}{l}\text { - Bötgger, McClinctock, } \\
\text { Klinger, } 2001 \\
\text { • Bötgger \& McClintock, } \\
2009\end{array}$ \\
\hline Ammonia & $\bullet<0.05 \mathrm{ppm}$ & $\begin{array}{l}\text { It should be closely controlled, on a weekly-basis at } \\
\text { least, higher values are to be avoided to prevent damage } \\
\text { to organisms and death }\end{array}$ & $\begin{array}{l}\text { - Basuyaux \& Mathieu, } \\
1999 \\
\text { • Lawrence et al., } 2003\end{array}$ \\
\hline Nitrate & $\cdot<50 \mathrm{ppm}$ & $\begin{array}{l}\text { The values are related to the ammonia values and } \mathrm{pH} \text {, } \\
\text { higher values must be avoided to prevent damage } \\
\text { to the organism }\end{array}$ & $\begin{array}{l}\text { - Bötgger, McClinctock, } \\
\text { Klinger, } 2001 \\
\text { - Bötgger and McClintock, } \\
2009\end{array}$ \\
\hline Phosphate & $\begin{array}{l}\cdot 0.8 \mathrm{ml} . \mathrm{L}-1 \text { inorganic } \\
\cdot 10 \mathrm{ml} . \mathrm{L}-1 \text { organic }\end{array}$ & Higher values will repress antimicrobial defenses & $\begin{array}{l}\text { - Bötgger, McClinctock, } \\
\text { Klinger, } 2001 \\
\text { - Bötgger and McClintock, } \\
2009\end{array}$ \\
\hline
\end{tabular}


TABLE 2 (Continued)

\begin{tabular}{|c|c|c|c|}
\hline Parameter & Range Value & Observations & References \\
\hline Antibiotics & $\begin{array}{l}\text { - Gentamycin } 10 \mathrm{mg} . \mathrm{L}-1 \\
\text { - Neomycin } 30 \mathrm{mg} . \mathrm{L}-1 \\
\text { - Novobiocin } 0.25 \mathrm{mg} . \mathrm{L}-1\end{array}$ & $\begin{array}{l}\text { Treat the individuals for } 2 \text { hours to the minimize } \\
\text { of disease to avoid massive death of individuals }\end{array}$ & $\begin{array}{l}\text { - Bötgger and McClintock, } \\
2009\end{array}$ \\
\hline Disease sign & & $\begin{array}{l}\text { Discoloration of epidermis surrounding the spines } \\
\text { or dermis papules, loss of spines or pedicelarius, } \\
\text { inflammation of dermis, loss of turgence, decoloration, } \\
\text { muscular contraction, evisceration in } \\
\text { sea cucumbers, autotomy of portion or entire arms. }\end{array}$ & - Jangoux, 1984 \\
\hline Stress sign & & $\begin{array}{l}\text { Lack of movement, podia retraction, loss of spines, } \\
\text { loss of turgence of the epidermis, inability to turn } \\
\text { over, evisceration of gut in sea cucumber, loss of arms, } \\
\text { decoloration of epidermis }\end{array}$ & • Hernández et al., 2004 \\
\hline
\end{tabular}

collection. First, when possible gloves are to be used to avoid possible infection (Scheibling \& Stephenson, 1984). After collection, echinoderms are to be kept in clean seawater at appropriate temperature and salinity, away from the sun and with aeration, when possible using a container that its able to maintain appropiate water temperature and aerate (i.e. http://www.hyparkspecialty.com/) to transport the organisms. When individuals are to be fixed for taxonomic identification, often relaxation is needed, menthol is frequently used and then individuals are fixed without being anesthetized. Since proper research regarding anesthetic for echinoderms is not available (Lewbart \& Mosley, 2012), $\mathrm{Cl}_{2} \mathrm{Mg} 7.5 \%$ should be used for at least 10 minutes. Even though there is no evidence that echinoderms will not feel pain with this solution, loss of movement is often observed (Van den Spiegel \& Jangoux, 1987). Individuals captured for experimental uses are to be transferred into the aquaria slowly, but first they have to be acclimatized to the temperature of the chamber and then relocated in the aquaria with seawater with adequate chemical and physical parameters. Closed re-circulating aquaculture systems (RAS) in the necessary scale are recommended (Grosjean, Spirlet, Gosselin, Vaitilingon, \& Jangoux, 1998; Chen \& Chang, 2015). These systems should allow feces to be transported through physical, mechanical and biological filters to allow the reuse of water minimizing the levels of toxic compounds (ammonia, phosphate, nitrate) that can affect physiology, production, microbial defenses (Basuyaux \& Mathieu, 1999; Lawrence, McBride, Plank, \& Shpigel, 2003; Böttger \& McClintock, 2009). Echinoderms are ectotherms and stenohaline osmoconformers therefore respiration depends on the oxygen levels in the seawater. Temperature affects oxygen solubility and determines the temperature of the body fluids. Moreover, temperature and salinity determine the osmotic characteristic of the body fluids. For these reasons, dissolved oxygen levels are to be maintained at high level and temperature and salinity are to be kept in a narrow range (Stickle \& Diehl, 1987; Hernández, Buckle, Guisado, Baron, \& Estavillo, 2004). Photoperiod is crucial, it determines gonadal cycles in many echinoderms (Mercier \& Hamel, 2009), and maintaining the photoperiod close to the season should be desirable. Animal density is important, in a crowded aquarium it is difficult to maintain proper seawater parameters and high densities often lead to a rapid spread of microbiological-based diseases (Sartori, Scuderi, Sansone, \& Gaion, 2014). Animal must be observed daily to detect individuals with signals of stress or diseases. Animal proper feeding is crucial and, to do so, basic knowledge of the species is needed. In starving experiments, individuals should not be maintained until death, at least not in large number and the Reduction principle is recommended. No experiences are to be made at least for a week after collection to minimize stress of the individuals. 
Proper protocol to anesthetize individuals is needed. However in the meantime submersion in $\mathrm{Cl}_{2} \mathrm{Mg} 7.5 \%$ for at least 10 minutes is to be used and the use of terminal anesthesia in 10\% ethanol as it is used in cephalopods should be considered (Moltschaniwskyj et al., 2007). For scientific purposes the Reduction principle applies, design of experiments is to be done with the minimal number of animals as statistically possible. These points are summarized in tables 1 and 2 .

\section{FINAL CONSIDERATION}

Is there any reason why we should not use ethics when working on echinoderms? This is a valid question every scientist and teacher should ask. We expect that the thoughts expressed in this work can be used as a starting point to think over our actions when doing research and teaching with echinoderms. We should always keep in mind that echinoderms are livings beings and they deserve an ethical consideration.

\section{ACKNOWLEDGEMENT}

We would like to thank the researchers who assist to the III Congreso Latinoamericano de Equinodermos for the encouragement to write this paper and to the reviewers who help us to improve the manuscript. The present work received finnancial supported from CONICET PIP 0352/14 and MinCyT PICT 2014-2042.

\section{RESUMEN}

¿La investigación en equinodermos merece una consideración ética? La reflexión ética tradicional centra la discusión en conflictos que afectan a los seres humanos. De acuerdo a la ética basada en la epistemología, es necesario tener datos empíricos para poder incluir a otros seres vivos en la consideración ética. En este sentido, se han realizado enormes esfuerzos científicos para demostrar que el sufrimiento animal es real. Sin embargo, la reflexión ética, hoy en día, se enfoca casi exclusivamente en especies de grandes vertebrados y algunas especies de pequeños, excluyendo por complete a los invertebrados. Por el otro lado, la epistemología basada en la ética cuestiona a la ética tradicional y sus supuestos. Esta nueva visión no exige la existencias de hechos que demuestren que los seres vivos deben ser considerados éticamente, puesto que considera a la ética antes que a los hechos. Por lo tanto, considera que todos los seres vivos deben ser tratados con respeto y se debe establecer una relación basada en la empatía. En este trabajo analizamos los avances realizados en la investigación de equinodermos en los últimos 3000 años y los diferentes usos que los humanos hacemos de estos organismos. Finalmente, enfatizamos que es necesaria una reflexión sobre nuestro comportamiento como investigadores enfocados en equinodermos y fomentamos el uso de la investigación éticamente responsable.

Palabras clave: Ética; Echinodermata; doctrina antropocéntrica; doctrina no antropocéntrica; principio de las 3R.

\section{REFERENCES}

Agassiz, A. (1881). Report on the Echinoidea dredged by H.M.S. Challenger during the Years 1873-1876. ZOOLOGY Part IX Challenger Reports.

Agassiz A. (1890). Notice of Calamocrinus diomedeae, a new stalked Crinoid from the Galapagos, dredged by the U. S. Fish Commission Steamer 'Albatross'. Bulletin of the Museum of Comparative Zoology, 20,165-167.

Aristotle. (350 B.C.E.) The History of Animals. Translated by por Richard Cresswell in 1862, Saint John's College, Oxford University, London

Basuyaux, O, \& Mathieu, M. (1999). Inorganic nitrogen and its effect on growth of the abalone Haliotis tuberculata Linneaus and the sea urchin Paracentrotus lividus Lamarck. Aquaculture International, 174, 95-107.

Boveri, T. (1901). Die Polarität von Oocyte, Ei und Larve des Strongylocentrotus lividus. Zoologische Jahrbücher. Abteilung für Anatomie und Ontogenie der Tiere Abteilung für Anatomie und Ontogenie der Tiere. 14, 630-653.

Böttger, S. A., McClintock, J. B., \& Klinger, T. S. (2001). Effects of inorganic and organic phosphates on feeding, feeding absorption, nutrient allocation, growth, and righting responses of the sea urchin Lytechinus variegatus. Marine Biology, 138, 741-751.

Böttger, S. A., \& McClintock, J. B. (2009). The effects of chronic inorganic and organic phosphate exposure on bactericidal activity of the coelomic fluid of the sea urchin Lytechinus variegatus (Lamarck) (Echinodermata: Echinoidea). Comparative Biochemistry and Physiology Part C: Toxicology \& Pharmacology, 150(1), 39-44. 
Briggs, E. \& Wessel, G. M. (2006). In the beginning... Animal fertilization and sea urchin development. Developmental Biology, 300, 15-26.

Brown, N. \& Eddy, S. (2015). Echinoderm Aquaculture. New Yersey, Wiley-Blackwell.

Brusca, R. C., Moore, W. \& Schuster, M. (2016). Invertebrates. Massachusetts, Sinauer Associated, Inc, Publishers.

Brewer, R. \& Konar, B. 2005. Chemosensory responses and foraging behavior of the seastar Pycnopodia helianthoides. Marine Biology 147: 789.

Burke, R. D., et al. 2006. A genomic view of the sea urchin nervous system. Developmental biology, 300(1), 434-460.

Campbell, C., Coppard, C., D'ABREO, D. \& Tudor-Thomas, R. 2001. Escape and Aggregation Responses of Three Echinoderms to Conspecific Stimuli. Biological Bulletin, 201: 175-185.

Cameron, C. B., Garey, J. R. \& Swalla, B. J. (2000). Evolution of the chordate body plan: new insights from phylogenetic analyses of deuterostome phyla Proceedings of the National Academy of Sciences, 97(9), 4469-4474.

Candelaria, A. G., Murray, M., File, S. K., \& García-Arrarás, J. E. (2006). Contribution of mesenterial muscle dedifferentiation to intestine regeneration in the sea cucumber Holothuria glaberrima. Cell and tissue research, 325, 55-65.

Candia-Carnevali, M. D., Bonasoro, F., Lucca, E., \& Thorndyke, M. C. (1995). Pattern of cell proliferation in the early stages of arm regeneration in the feather star Antedon mediterranea. The Journal of Experimental Zoology, 272, 464-474.

Chandroo, K. P.; Duncan, I. J. H. \& Moccia, R. D. (2004) "Can fish suffer?: Perspectives on sentience, pain, fear, and stress", Applied Animal Behavior Science, 86 , pp. $225-250$.

Cheney, J., \& Weston, A. (1999). Environmental ethics as environmental etiquette: Toward an ethics-based epistemology. Environmental Ethics, 21(2), 115-134.

Clark, H.L. (1902). Papers from the Hopkins Stanford Galapagos Expedition. Proceeding of the Washington Academy of Science, IV, 521-531.

Council, C. (1984). Guide to the care and use of Experimental Animals. CCAC, Ottawa, 2, 176-187.

De Morgan, W. (1913). The Echinoderms collected by the "Huxley" from the North Side of the Bay of Biscay in August, 1906. Journal of the Marine Biological Association of the United Kingdom, 9, 530-541.
De Tornos, L. (1839). Compendio de historia natural dividido en los tres ramos de mineralogía, botánica y zoología. Madrid, Imprenta Salvador Albert.

Derbès, A. A. (1847). Observations sur le Méchanisme et les Phenomènes qui Accompagnent la Formation de l'Embryon chez l'Oursin Comestible. Annales des Sciences Naturelles - Zoologie et Biologie Animale, 8, 80-98.

Dess, N K., \& Foltin, R W. (2005). The ethics cascade. In C. K. Akins, S. Panicker, \& C. Cunningham (Eds.). Laboratory animals in research and teaching: Ethics, care, and methods (pp. 31-39). Washington, DC: American Psychological Association.

Dolmatov, I.Y. (1988). Structure of the aquapharyngeal complex in the holothurian Eupentacta fraudatrix under the normal conditions and during regeneration. Canadian Science Dissertation. Vladivostok: Institute of Marine Biology, Far East Division of the USSR Academy of Sciences.

Dolmatov, I. Y., \& Ginanova, T. T. (2001). Muscle Regeneration in Holothurians. Microscopy Research and Technique, 55, 452-463.

Dufossé, A. (1847). Observations sur le developpement des oursins. Annales des Sciences Naturelles, 7, 44-52.

Edelman, D. B. \& Seth, A. K. (2009) "Animal consciousness: A synthetic approach", Trends in Neuroscience, 9, pp. 476-484.

Ehlers, U. (1997), Ultrastructure of the Statocysts in the Apodous Sea Cucumber Leptosynapta inhaerens(Holothuroidea, Echinodermata). Acta Zoologica, 78: 61-68.

Eisen, A. (1995). A Holistic Approach to Teaching a Laboratory Using Sea Urchin. Development as an Example System. In C. A. Goldman Ed.) Tested studies for laboratory teaching (pp. 25-32). Atlanta, Ge: Proceedings of the 16th Conference of the Association for Biology Laboratory Education.

Ellwood, R.W. 2011. Pain and suffering in invertebrates? Institute for Laboratory Animal Research, $52,175-184$.

Frey, H. \& Luckart, R. (1847). Zootomie. Voss, Germany: Leipzig,

Furukawa, R., Funabashi, H., Matsumoto, M., \& Kaneko, H. (2012). Starfish ApDOCK protein essentially functions in larval defense system operated by mesenchyme cells. Immunology and cell biology, 90(10), 955-965.

Garner, S., Zysk, I., Byrne, G., Kramer, M., Moller, M. Taylor, V., \& Burke, R. D. (2016). Neurogenesis in sea urchin embryos and the diversity of deuterostome neurogenic mechanisms. Development, 143, 286-297. 
Griffin, D. R. \& Speck, G. B. (2004). "New evidence of animal consciousness", Animal Cognition, 7, 5-18.

Grosjean, J. (2001). Growth model the reared sea urchin Paracentrotus lividus (Lamarck, 1816). PhD Thesis, Universite Libre de Bruxelles.

Grosjean, P., Spirlet, C., Gosselin, P., Vaitilingon, D, \& Jangoux, M. (1998). Land-Base, close-Cycle echiniculure of Paracentrotus lividus (Larmck) (Echinoidea: Echinodermata): A long-term experiment at a pilot scale. Journal of Shellfish Research 17(5), 1523-1531.

Guariglia, O. \& Vidiella, G. (2011). Breviario de ética. Buenos Aires, Edhasa.

Hagen, N.T. \&. Andersen, O.B. (2002) Stabell Alarm responses of the green sea urchin, Strongylocentrotus droebachiensis, induced by chemically labelled durophagous predators and simulated acts of predation. Marine Biology, 140: 365-374.

Halanych, K. M. (1995). The phylogenetic position of the pterobranch hemichordates based on $18 \mathrm{~S}$ rDNA sequence data. Molecular Phylogenetics and Evolution, 4, 72-76.

Hernández, M., Buckle, F., Guisado, C., Barón, B., \& Estavillo, N. (2004). Critical termal maximun and osmotic pressure of the red sea urchin Strongylocentrotus franciscanus acclimated at different temperaturas. Journal of Thermal Biology, 29, 231-236.

Hertwig, O. (1876). Beiträge zur Kenntniss der Bildung, Befruchtung und Theilung des thierischen Eies. Morphologisches Jahrbuch, 1, 374-434.

Ho, E. C. H. (2015). A simple animal model for characterizing gene regulatory control of an immune respons (PhD Thesis). University of Toronto, Toronto.

Jangoux, M. (1984). Diseases of echinoderms. Helgolander Meeresunters, 37: 207-216.

Klein, J. (1734). Naturalis dispositio echinodermatum. Schreiber, Danzig.

Lamarck, J. B. (1809). Philosophie zoologique, ou, Exposition des considérations relative à l'histoire naturelle des animaux. Paris: Imprimerie de Duminil-Lesueur.

Lawrence, J.M. (1975). The effect of temperaturesalinity combinations on the functional wellbeing of adult Lytechinus variegatus (Lamarck) (Echinodermata:Echinoidea). Journal of Experimental Marine Biology and Ecology, 18, 271-275.

Lawrence, J.M. (2007). Edible sea urchins: Use and lifehistory strategies, In J. M. Lawrence (Ed.) Developments in Aquaculture and Fisheries Science (pp. 1-6). New York, NY: Elsevier
Lawrence, J. M., McBride, S. C., Plank, L. R., \& Shpigel, M. (2003). Ammonia tolerance of the sea urchins Lytechinus variegatus, Arbacia punctulata, Strongylocentrotus franciscanus, and Paracentrotus lividus. pp. 233-236. In: J. P. Féral, \& B. David (eds.). Echinoderm Research 2001. Lisse: A.A. Balkema.

Leopold, A. (1949). A Sand County Almanac. Oxford University Press, New York.

Leuckart, R. (1854). Zoologische Untersuchungen. Vol. 3. Heteropoden, Zwitterschnecken, Hectocotyliferen. Giessen, Germany.

Lewbart, G.A. \& Mosley, C. (2012). Clinical anesthesia and analgesia in invertebrates. Journal of Exotic Pet Medicine, 21:59-70

Lewis, J. B. (1968). The function of the sphaeridia of sea urchins. Canadian Journal of Zoology, 46(6), 1135-1138.

Linnæus, C. (1758). Systema naturce per regna tria naturce, secundum classes, ordines, genera, species, cum characteribus, differentiis, synonymis, locis. Holmiae: Impensis Direct. Laurentii Salvii.

Mashanov, V.S., Zuelva, O.R, \& Heinzeller, T. 2008. Regeneration of the radial nerve cord in a holothrian: A promising new model system for studying post-traumatic recovery in the adult nervous system. Tissue \& Cell, 40, 351-372.

Mashanov, V; Zueva, O; Rubilar, T; Epherra, L; GarcíaArráras, J. 2016. Echinodermata. In A. SchmidtRhaesa; S. Harzsch; G. Purschke (Eds.), Structure and Evolution of Invertebrate Nervous Systems (pp. 665-688) London: Oxford University Press

Mather, J.A. 2015 An invertebrate perspective on pain. Animal Sentience 18, 1-3.

McClay, D.R. (2011). Evolutionary crossroads in developmental biology: sea urchins Development, 138, 2639-2648.

Mercier, A. \& Hamel, J. 2009. Gametogenesis. In A. Mercier, J. Hamel (Eds), Advances in Marine Biology Vol 55 (pp.7-70), London: Elsevier Ltd

Metchnikoff, I., 1893. Lectures on the comparative pathology of inflammation. London: Kegan Paul, Trench, Truener \& Co. LTD.

Moltschaniwskyj, N. A., Hall, K., Lipinski, M. R., Marian, J. E. A. R., Nishiguchi, M., Sakai, M., Shulman, D. J., Sinclair, B., Sinn, D. L., Staudinger, M., Van Gelderen, R., Villanueva, R., \& Warnke, K. (2007). Ethical and welfare considerations when using cephalopods as experimental animals. Review in Fish Biology and Fishery, 17, 455-476. 
Moore, P.A. \& Lepp, D.M.E. (1997). Role of Chemical Signals in the Orientation Behavior of the Sea Star Asterias forbesi. Biological Bulletin 192: 410-417.

Perseke, M., Golombek, A., Schlegel, M., \& Struck, T.H. (2013) The impact of mitochondrial genome analyses on the understanding of deuterostome phylogeny. Molecular Phylogenetic and Evolution, 66, 898-905.

Pinsino, A., Thorndyke, M.C., \& Matranga, V. (2007). Coelomocytes and post-traumatic response in the common sea Star Asterias rubens. Cell Stress \& Chaperones, 12, 331-341.

Raible, F., Tessmar-Raible, K., Arboleda, E., Kaller, T., Bork, P., Aendt, D., \& Arnone, M.I. (2006). Opsins and clusters of sensory G-protein-coupled receptors in the sea urchin genome. Developmental Biology, $300,461-475$.

Repolho, T. (2012). Evaluation of Paracentrotus lividus (Lamarck, 1816) exotrophic larvae as live feed for marine decapod crustacean larvae. $\mathrm{PhD}$ Thesis. Universidad de Lisboa.

Russell, W.M.S. \& Burch, R.L. (1959). The Principles of Humane Experimental Technique, London: Methuen.

Salacroux, A. P. G. (1840). Nuevos elementos de Historia Natural. Madrid, Imprenta de Verges.

San Miguel-Ruiz, J.E. \& García-Arrarás, J.E. (2007). Common cellular events occur during wound healing and organ regeneration in the sea cucumber Holothuria glaberrima. BioMed Central Developmental Biology, $7,115-124$.

Sartori, D., Scuderi, A., Sansone, G., \& Gaion, A. (2014). Echinoculture: the rearing of Paracentrotus lividus in a recirculating aquaculture system-experiments of artificial diets for the maintenance of sexual maturation. Aquaculture International, 23, 111-125.

Scheibling, R. E., \& Stephenson, R. L. (1984). Mass mortality of Strongylocentrotus droebachiensis (Echinodermata: Echinoidea) of Nova Scotia, Canada. Marine Biology, 78, 153-164.

Sherman, E. (2015). Can sea urchins beat the heat? Sea urchins, thermal tolerance and climate change. PeerJ, 3, e1006. https://doi.org/10.7717/peerj.1006
Smith, A.B. (2005). Echinoderms (Other Than Echinoids). In R. Cocks \& I. Plimer (Eds.), Encyclopedia of Geology (pp. 334-341). Elsevier, Oxford.

Stickle, W. B. \& Diehl, W. J. (1987). Efects of salinity on echinoderms. In M. Jangoux \& J.M. Lawrence (Eds.), Echinoderm Studies Vol. 2 (pp. 235-285). Rotterdam, The Netherlands: A.A. Balkema,

Swalla, B.J. \& Smith, A.B. (2008) Deciphering deuterostome phylogeny: molecular, morphological and palaeontological perspectives. Philosophical Transactions of the Royal Society B 363, 1557-1568.

Telford, M. J., Lowe, C. J., Cameron, C. B., Ortega-Martinez, O., Aronowicz, J., Oliveri, P., \& Copley, R. R. (2014). Phylogenomic analysis of echinoderm class relationships supports Asterozoa. Proceedings of the Royal Society of London B: Biological Sciences, 281, 20140479.

Théel, H. (1882). Report on the Holothurioidea, dredged by H.M.S. Challenger during the Years 1873-1876. ZOOLOGY Part IX Challenger Reports.

Ullrich-Lüter, E. M., Dupont, S., Arboleda, E., Hausen, H., \& Arnone, M. I. (2011). Unique system of photoreceptors in sea urchin tube feet. Proceedings of the National Academy of Sciences, 108(20), 8367-8372.

Van den Spiegel, D., \& Jangoux, M. (1987). Cuverian tubules of the holothuroid Holothuria forskali (Echinodermata): a morphofunctional study. Marine Biology, 96, 263-275.

Vidal, E.A.G., Villanueva, R., Andrade, J.P., Gleadall, I.G., Iglesias, J., Koueta, N., Rosas, C. Segawa, S., Grasse, B., Franco-Santos, R.M., Albertin, C.B., CaamalMonsreal, C., Chimal, M.E., Edsinger-Gonzales, E., Gallardo, P., Le Pabic, C., Pascual, C., Roumbedakis, K, \& Wood, J. (2014). Cephalopod Culture: Current Status of Main Biological Models and Research Priorities. In E.A.G. Vidal (Ed), Advances in Marine Biology, Advances in Cephalopod Science: Biology, Ecology, Cultivation and Fisheries (pp. 1-98), London: Elsevier Ltd.

Weston, A. (2009). The incomplete eco-philosopher: essays from the edges of environmental ethics. New York, SUNY Press. 